\title{
Influence of fertilization and care systems on productivity and quality of winter wheat grain
}

\author{
Lukashchuk L. ${ }^{1}$, Kurach O. ${ }^{2}$, Snizhok O.. ${ }^{3}$, Huk L. ${ }^{4}$, Kucherova A. ${ }^{5}$ \\ 1-4Institute of Agriculture of Western Polissia of NAAS \\ 5 Rivne Str., Shubkiv village, Rivne region, 35325, Ukraine \\ ${ }^{5}$ National University of Water and Environmental Engineering \\ 11 Soborna Str., Rivne, 33028, Ukraine \\ e-mail: ${ }^{1-4}$ rivne_apv@ukr.net, ${ }^{5}$ a.v.kucherova@nuwm.edu.ua \\ ORCID: ${ }^{1}$ 0000-0003-2125- 3790, ${ }^{2} 0000-0002-1343-097 X,{ }^{3} 0000-0002-2239-1810,{ }^{4} 0000-0001-8200-$ \\ 7326, ${ }^{5} 0000-0003-2483-8169$
}

Goal. To determine the influence of the system of mineral nutrition and care of winter wheat crops on the formation of grain yield in the Western Forest-Steppe. Methods. Visual — to determine the phenological phases of growth and development of culture; estimation - to determine the parameters of crop structure and yield; chemical - to determine the content of nutrients in the soil; mathematical and statistical - to assess the reliability of research results; calculation-comparative - to analyze economic efficiency. Results. The data are given of results of researches in cultivation of winter wheat on an intensive technology and how at the same time under the influence of systems of fertilizer and care of crops its productivity changed. Analysis of yield data showed that fertilizer systems, which used different types of fertilizers, provided a significant increase in yield on average over 3 years by $32.5-39.5 \%$ compared to the control, where fertilizers were used only as the main fertilizering. Double application of growth stimulant Vimpel 2 in combination with pesticides and microfertilizer Oracle multicomplex in the tillering phase and on the flag leaf helped to increase crop productivity by $9.6-10.9 \%$. Conclusions. According to the results of research it is established that the cultivation of winter wheat using fertilizer system N160R90K120 with foliar fertilization with Oracul colofermin phosphorus $(2.5 \mathrm{l} / \mathrm{ha}$ ) in combination with 2 -fold spraying of crops with growth stimulant Pennant $2(0.6 \mathrm{~kg} / \mathrm{ha})$ and microfertilizer multicomplex $(2 \mathrm{l} / \mathrm{ha})$ provided the highest yield $-7.13 \mathrm{t} / \mathrm{ha}$ (increase was $14.9 \%$ ).

Key words: structure, quality, fertilization, microfertilizers, gluten.

DOI: https://doi.org/10.31073/agrovisnyk202010-02

The most important component of the agro-industrial complex is the grain industry, which occupies a leading place in the structure of the agricultural sector of the Ukraine's economy. The welfare of the population, guaranteeing national food security, export opportunities of the country depend on the level of efficiency of its development. To maintain positions in the international arena for the sale of grain, domestic producers need to constantly invest in improving the efficiency of the industry, to introduce innovative technologies for the production of competitive products [1,2].

In this regard, only a scientific-based correction of the component composition and amount of fertilizers with the inclusion of all necessary for the formation of healthy and highly productive plant organisms mineral nutrients in combination with highly effective plant protection products and biologically active substances can minimize the gap between actual and potential crop productivity and their varieties, reduce production costs and increase the efficiency of grain production $[3,4,5]$. Therefore, there is a need to study the effect of fertilization systems of different fertilizer saturation and crop care on the productivity of winter wheat.

Drought, cooling and temperature rising during the early stages of winter crops lead to reduced plant uptake of nutrients from the soil. That is why it is necessary to constantly monitor the situation in each field and have the own technology methods of plant support and supplementation to the main nutrition in critical periods of plant growth and development - foliar feeding [6].

Foliar feeding of winter wheat with a solution of urea with magnesium sulfate and microelements on the background of the optimal ratio of biogenic elements in the soil fully provides plants with nitrogen, has a positive effect on the formation of high yields, increases protein content in marketable products [7].

It is proved that the beginning and the middle of the booting and the appearance of the second stem node is a critical period for winter wheat to provide moisture and nutrition. Therefore, in this period, when winter wheat plants begin booting, it is important to provide them with a complex of macro-and microelements. This allows to effectively eliminate the deficiency of essential nutrients, stimulates the growth of the root system, increases resistance to biotic and abiotic stresses and to the lodging of plants, increases yields and product quality [8].

Analyzing foreign and national literature references, it was found that the use of fertilizers with macro- and chelated forms of microelements for foliar feeding significantly affected the grain productivity of plants and allowed to obtain increases in winter wheat yield by an average of $10-15 \%$ with an increase in protein 
content in grain from 6 to $1.4 \%$, gluten by $3.50-4.3 \%$ [9]. It is also effective to use growth stimulants that increase the grain yield of winter wheat on $0.3-0.7 \mathrm{t} / \mathrm{ha}$ and improve grain quality [10].

The objective of the researches is to determine the effect of the system of mineral nutrition and care of winter wheat crops on obtaining the maximum possible yield of high-quality grain in the conditions of the Western Forest-Steppe.

Materials and research methods of the research work was carried out during 2016-2018 in the field crop rotation on typical low-humus light loam chernozem soil which had the following agrochemical parameters of 0-30 cm layer: the content of humus according to Tiurin was $1.96 \%$, the content of alkali-hydrolyzable nitrogen to Kornfield was $79.2 \mathrm{mg} / \mathrm{kg}$ of soil, mobile phosphorus (P2O5) and potassium (K2O) according to Kirsanov was 251 and $109 \mathrm{mg} / \mathrm{kg}$ of soil respectively, (pH (salt) was 6.2, hydrolytic acidity according to Kapen - $1.14 \mathrm{mg}$.- eq./100 $\mathrm{g}$ of soil.

Winter rape was a forecrop.. The area of the accounting plot in the experiments was $25 \mathrm{~m}^{2}$, the repetition was four times. Winter wheat cultivar was Darunok Podillia. The sowing rate was 5.0 million similar seeds per hectare.

The research was based on fertilization systems (factor A) at different doses, application times: 1. $\mathrm{N}_{30} \mathrm{P}_{90} \mathrm{~K}_{120}$ - background; 2. Background $+\mathrm{N}_{60}$ (lime-ammonium nitrate) - after SVR + $\mathrm{N}_{60}$ (ammonium nitrate) - initial booting $+\mathrm{N}_{10}$ (urea) - a flag leaf; 3. Background $+\mathrm{N}_{30}$ (lime-ammonium nitrate) - after SVR $+\mathrm{N}_{30}$ (nitrogen-sulfur fertilizer) - after SVR + $\mathrm{N}_{60}$ (ammonium nitrate) - initial booting. $+\mathrm{N}_{10}$ (urea) - flag leaf; 4. Background $+\mathrm{N}_{60}$ (lime-ammonium nitrate) - after SVR + Oracul colofermin phosphorus, $2.5 \mathrm{l} / \mathrm{ha}-$ after $\mathrm{SVR}+\mathrm{N}_{60}$ (ammonium nitrate) - initial booting $+\mathrm{N}_{10}$ (urea) - flag leaf; 5 . Background $+\mathrm{N}_{50}$ (lime-ammonium nitrate) - after SVR + $\mathrm{N}_{10}$ (urea foliar) - after SVR + Oracul colofermin phosphorus, 2.5 I/ha - after SVR + $\mathrm{N}_{60}$ (ammonium nitrate) - initial booting $+\mathrm{N}_{10}$ (urea) - flag leaf. Crop care (factor $\mathrm{B}$ ) included the application of growth stimulant Vimpel $2(0.6 \mathrm{~kg} / \mathrm{ha})$ and the variant (without treatment).

The system of plant protection at the experimental plot included application of herbicide Calibr, $75 \%$ - $0.06 \mathrm{~kg} / \mathrm{ha}$, three fungicidal treatments with preparations such as: 1 - Birex, 50\% e.c. - $0.6 \mathrm{l} / \mathrm{ha} ; 2$ Acanto plus, $50 \%$ e.c. - $0.6 \mathrm{l} / \mathrm{ha}$; 3 - Abacus, $18.3 \%$ e.c. - $1.6 \mathrm{l} / \mathrm{ha}$, one insecticide treatment $\mathrm{Bl}-58 \mathrm{new}$ - $1.5 \mathrm{l} / \mathrm{ha}$, retardant Chlomequid, w.s.c. - $2.0 \mathrm{l} / \mathrm{ha}$.

Field experiments were conducted using the following methods as estimation-weight, chemical, physical, mathematical-statistical and calculation-comparative.

Weather conditions in the years of research were not entirely favorable for the cultivation of spiked cereals.

The period of soil preparation for sowing winter crops for the 2016 harvest was characterized by dry weather. The reserves of productive moisture at the end of the second decade of September for winter rape as a forecrop were critical: in the arable layer it was $0.89 \mathrm{~mm}$, in the meter $-38.34 \mathrm{~mm}$, which made it impossible for seeds to germinate at all. The situation with moisture supply was significantly improved in the third decade of September, when $58.5 \mathrm{~mm}$ of precipitation fell, i.e. $127 \%$ of the monthly norm.

A stable average daily temperature less than $+5^{\circ} \mathrm{C}$ was observed from November 21 .

Winter weather was characterized by high temperature conditions in December and February (above the norm by $4.5^{\circ} \mathrm{C}$ and $6.9^{\circ} \mathrm{C}$, respectively). At the beginning of January there observed the lowest temperatures to minus $19.6^{\circ} \mathrm{C}$, the absence of snow cover in contrast to strong winds caused significant damage to leaf blades on winter wheat crops and the death of some plants. Precipitation for the whole winter period was $88.6 \mathrm{~mm}(89.4 \%$ of the norm). The snow covered the land for a short period of time and did not exceed $10 \mathrm{~cm}$. The soil froze to $35 \mathrm{~cm}$. Vegetation resumed in the third decade of February.

Reserves of productive moisture at the time of vegetation renewal were in the arable layer of 0-20 $\mathrm{cm}-45.3 \mathrm{~mm}$, in the meter - $142.9 \mathrm{~mm}$. During the spring-summer vegetation, they were sufficient for normal plant development. Maturing of winter wheat crops took place at the end of the second decade of July.

The period of soil preparation for the winter of 2017 was also characterized by hot dry weather. At higher temperatures in August and September, only 35.0 and $3.3 \mathrm{~mm}$ of precipitation fell, respectively, which made it impossible to carry out high-quality tillage and winter sowing. However, in October there was a decrease in air temperature with excessive rainfall (306\% of the climatic norm). The cessation of active vegetation of plants occurred on October 30. There were no critical conditions for overwintering winter crops. From the third decade of February there was a significant increase in temperature, which led to the renewal of plant vegetation.

Weather conditions in the autumn of 2017 were characterized by a moderate temperature and excessive rainfall. Thus, in September the average daily air temperature was $14.3^{\circ} \mathrm{C}$, in October $-8.5^{\circ} \mathrm{C}$, in November $-8.5^{\circ} \mathrm{C}$ at the climatic norm of $13.1^{\circ} \mathrm{C}, 8,5^{\circ} \mathrm{C}$ and $2.2^{\circ} \mathrm{C}$, respectively. The first frosts $\left(0.7^{\circ} \mathrm{C}\right.$ below zero) were observed at night in early October. When the average daily temperature of not less than $5^{\circ} \mathrm{C}$ above zero was recorded on November 11, i.e. at the level of many years and became stable, active vegetation of winter crops was checked in growth. During the autumn the level of atmospheric precipitation accounted for $98.5 \mathrm{~mm}$ in September, which was $205 \%$ of the climatic norm, in October it was $74.1 \mathrm{~mm}$ (195\%), in November it was $46.9 \mathrm{~mm}$ (130\%).

December was characterized by humid weather with increased heat supply at a monthly average daily air temperature plus $1.3^{\circ} \mathrm{C}$, which is $3.7^{\circ} \mathrm{C}$ above the climatic norm. Its third decade was extremely 
warm, when this indicator exceeded the norm by $5.6^{\circ} \mathrm{C}$, and the temperature maximum on some days reached $9.4^{\circ} \mathrm{C}$. During the month, $70 \mathrm{~mm}$ of precipitation (189\% of the climatic norm) fell in the form of rain and wet snow.

At the beginning of January 2018, there was a cooling, but the weather was quite changeable: there were fluctuations in the average daily air temperature from plus $4.7^{\circ} \mathrm{C}$ to minus $12.5^{\circ} \mathrm{C}$. In January, $28.1 \mathrm{~mm}$ of precipitation fell (at the monthly rate of $30 \mathrm{~mm}$ ). At the end of the first decade there was a complete freezing of the soil.

The weather in February differed close to the climatic norm by the average daily temperature in the first and second decades (minus $2.8^{\circ} \mathrm{C}$ and minus $3.5^{\circ} \mathrm{C}$, respectively) and an anomalous decrease of this indicator in the third decade to minus $10.6^{\circ} \mathrm{C}$ at the norm of minus $3.8^{\circ} \mathrm{C}$. The coolest periods were the middle of the first decade and the end of the month, when the minimum air temperature was $17.4^{\circ} \mathrm{C}-$ $23.2^{\circ} \mathrm{C}$ below zero. The monthly precipitation $(31.4 \mathrm{~mm})$ corresponded to long-term data.

Snow cover appeared in the second decade of January. Its greatest height (about $20 \mathrm{~cm}$ ) was observed in late February. The maximum freezing of the soil was recorded in late January. However, a jump in air temperature to positive values (during the day to $6-8^{\circ} \mathrm{C}$ above zero) in the period from January 28 to February 3 led to the ending of snow cover and thawing of the soil to a depth of $12 \mathrm{~cm}$, and subsequent cooling resulted in refreezing of its top layer. At the end of the winter, the depth of soil freezing was 23 $\mathrm{cm}$ with an unfrozen layer at a depth of $9-12 \mathrm{~cm}$.

The lowest soil temperature at the depth of lodging the tillering node for the whole winter period $\left(6.2^{\circ} \mathrm{C}\right.$ below zero) was observed in the second half of January. At the end of February, this figure was $5.1^{\circ} \mathrm{C}$.

Thus, winter weather conditions were not critical for overwintering of winter wheat.

March 2018 appeared to be cold and wet. During the month, $35.2 \mathrm{~mm}$ of precipitation fell $(135.4 \%$ of the climatic norm). The average daily temperature was $1.9^{\circ} \mathrm{C}$ below zero, which is $2.2^{\circ} \mathrm{C}$ lower than the long-term indicator. Vegetation resumed on March 30. Reserves of productive moisture at this time were in the layer of $0-20 \mathrm{~cm} \mathrm{27-29} \mathrm{mm,} \mathrm{0-100} \mathrm{cm} \mathrm{-} \mathrm{166-169} \mathrm{mm.} \mathrm{April} \mathrm{was} \mathrm{characterized} \mathrm{by} \mathrm{hot} \mathrm{dry} \mathrm{weather,}$ especially in the second decade, when in the absence of precipitation, the average daily air temperature was twice the norm and amounted to $14.6^{\circ} \mathrm{C}$. In general, only $10.1 \mathrm{~mm}$ of precipitation fell during the month, i.e. a quarter of the climatic norm. The average daily air temperature for the month was $13.4^{\circ} \mathrm{C}$, which is $5.7^{\circ} \mathrm{C}$ higher than long-term data. Hot weather was observed in May. The average daily air temperature was $19.1^{\circ} \mathrm{C}$, which is $4.3^{\circ} \mathrm{C}$ higher than the average one for the years. Precipitation fell in the amount of $32.8 \mathrm{~mm}(58.6 \%$ of the climatic norm) only in the second decade. The first two decades of June were also characterized by a higher temperature regime of $3.7^{\circ} \mathrm{C}$ and $3.4^{\circ} \mathrm{C}$ above the norm, respectively, and insufficient moisture supply. The end of the month at moderate temperatures was rainy. Rainy weather was observed in the second half of July, which greatly complicated the harvest. The crops ripened at the beginning of the second decade of the month, but due to daily rains they were harvested in early August.

Research results and their discussion. Analysis of the data showed that fertilization systems, which involved the use of different types of fertilizers to crop feeding, provided a significant increase in yield on average over 3 years by $32.5-39.2 \%$ compared to the control, where fertilizers were applied only to the main fertilization (Table 1). Double application of growth stimulant Vimpel 2 (0.6 kg/ ha) in combination with pesticides and microfertilizer Oracul multicomplex (2 l/ ha) in the tillering phase and on the flag leaf increased crop productivity by $9.6-10.9 \%$.

1. Yield of Darunok Podillia winter wheat depending on fertilization and crop care systems, average for 2016-2018

\begin{tabular}{|c|c|c|c|c|c|c|}
\hline \multirow{4}{*}{$\begin{array}{c}\text { Fertilization } \\
\text { (factor A) }\end{array}$} & \multirow{4}{*}{$\begin{array}{l}\text { Crop care } \\
\text { (factor B) }\end{array}$} & \multicolumn{5}{|c|}{ Average } \\
\hline & & \multirow{3}{*}{$\begin{array}{l}\text { Crop } \\
\text { yield, } \\
\text { t/ha }\end{array}$} & \multicolumn{4}{|c|}{ Growth } \\
\hline & & & \multicolumn{2}{|c|}{$\begin{array}{c}\text { From } \\
\text { fertilization }\end{array}$} & \multicolumn{2}{|c|}{$\begin{array}{c}\text { From crop } \\
\text { care }\end{array}$} \\
\hline & & & t/ha & $\%$ & t/ha & $\%$ \\
\hline \multirow{2}{*}{$\mathrm{N}_{30} \mathrm{P}_{90} \mathrm{~K}_{120}$ - background } & 1 & 4,67 & - & - & - & - \\
\hline & 2 & 5,12 & - & - & 0,45 & 9,6 \\
\hline \multirow{2}{*}{$\begin{array}{l}\text { Background }+\mathrm{N}_{60} \text { (lime-ammonium nitrate) } \\
- \text { after SVR }+\mathrm{N}_{60} \text { (ammonium nitrate) }- \\
\text { initial booting }+\mathrm{N}_{10} \text { (urea) }- \text { flag leaf }\end{array}$} & 1 & 6,19 & 1,52 & 32,5 & - & - \\
\hline & 2 & 6,79 & 1,67 & 32,6 & 0,60 & 9,7 \\
\hline \multirow{2}{*}{$\begin{array}{l}\text { Background }+\mathrm{N}_{30} \text { (lime-ammonium nitrate) } \\
\text { - after SVR }+\mathrm{N}_{30} \text { (nitrogen-sulfur fertilizer) - } \\
\text { after SVR }+\mathrm{N}_{60} \text { (ammonium nitrate) - initial } \\
\text { booting. }+\mathrm{N}_{10} \text { (urea) - flag leaf }\end{array}$} & 1 & 6,24 & 1,57 & 33,6 & - & - \\
\hline & 2 & 6,90 & 1,78 & 34,8 & 0,66 & 10,6 \\
\hline
\end{tabular}




\begin{tabular}{|c|c|c|c|c|c|c|}
\hline \multirow{2}{*}{$\begin{array}{l}\text { Background }+\mathrm{N}_{60} \text { (lime-ammonium nitrate) } \\
-\quad \text { after SVR }+ \text { Oracul colofermin } \\
\text { phosphorus, } 2.5 \text { I/ha }- \text { after SVR }+\mathrm{N}_{60} \\
\text { (ammonium nitrate) }- \text { initial booting }+\mathrm{N}_{10} \\
\text { (urea) - flag leaf }\end{array}$} & 1 & 6,44 & 1,77 & 37,9 & - & - \\
\hline & 2 & 7,13 & 2,01 & 39,2 & 0,69 & 10,7 \\
\hline \multirow{2}{*}{$\begin{array}{l}\text { Background }+N_{50} \text { (lime-ammonium nitrate) } \\
- \text { after SVR }+N_{10} \text { (urea foliar) }- \text { after SVR }+ \\
\text { Oracul colofermin phosphorus, } 2.5 \text { I/ha - } \\
\text { after SVR }+N_{60} \text { (ammonium nitrate) }- \text { initial } \\
\text { booting }+N_{10} \text { (urea) }- \text { flag leaf }\end{array}$} & 1 & 6,40 & 1,73 & 37,0 & - & - \\
\hline & 2 & 7,10 & 1,98 & 38,7 & 0,70 & 10,9 \\
\hline
\end{tabular}

Note: 1-care system without Vimpel 2 application; 2-care system with Vimpel 2 application.

$L S D_{05}$, $t /$ ha $\quad$ factor $A-0.21$, factor $B-0.15$, factor interaction $A B-0.30$

It should be noted that the substitution of $50 \%$ of lime-ammonium nitrate for nitrogen-sulfur fertilizer (at a dose of $\mathrm{N}_{30}$ ) to feed crops during spring vegetation renewal (SVR) provided a significant increase in yield compared to the varient where $\mathrm{N}_{60}$ was applied only in the form of lime-ammonium nitrate.

Foliar feeding of winter wheat crops after vegetation renewal with microfertilizer-compensator of Oracul colofermin phosphorus at a rate of $2.5 \mathrm{l} / \mathrm{ha}(1.05 \mathrm{~kg} / \mathrm{ha}$ of phosphorus) allowed additionally to obtain $0.16-0.23 \mathrm{t} / \mathrm{ha}(4.0-5.0 \%)$ on average for a period of 3 years relative to the variant where it was not applied. Compared with the control, the increase in yield was 38.7-39.2\%. However, simultaneous application of urea and phosphorus fertilizer at a dose of $\mathrm{N}_{10}$ did not increase crop productivity. It should be mentioned that the effectiveness of foliar feeding in the early spring period is significantly increased by adding growth stimulant Vimpel $2(0.6 \mathrm{~kg} / \mathrm{ha})$ to the tank mixture of pesticides.

At this, grain output increased on average by $0.69-0.70 \mathrm{t} / \mathrm{ha}(10.7-10.9 \%)$ over the years of research. The fertilization and crop care system had a significant impact on the formation of individual elements of the crop structure (Table 2). In particular, feeding of winter wheat crops contributed to an increase in the density of productive stemstand by $12.6-21.0 \%$ compared to the control variant. The highest indicator was in varient 4 (on average $533-558 \mathrm{pcs} / \mathrm{m}^{2}$ for the period of 3 years), where feeding with liquid phosphorus fertilizer was carried out. However, this indicator changed at only $4.0-5.4 \%$ depending on crop care.

Early spring foliar feeding with phosphorus, phosphorus and nitrogen had a positive effect on the graininess of the ear of the winter wheat. In these variants, it accounted for 42.6-45.9 pieces. and was higher by $2-3$ grains compared to the variants where it was not carried out and by $6-8$ grains compared to the control. The weight of grain from the ear changed little from the forms of fertilizers in the early spring feeding. The use of the growth stimulant Vimpel 2 had a more significant effect, which ensured its increase by $0.13-0.15 \mathrm{~g}(7.2-9.2 \%)$.

2. Yield structure of Darunok Podillia winter wheat depending from fertilization and crop care systems, average for 2016-2018

\begin{tabular}{|c|c|c|c|c|c|}
\hline $\begin{array}{l}\text { Fertilization system } \\
\quad(\text { factor A) }\end{array}$ & $\begin{array}{l}\text { Crop care } \\
\text { (factor B) }\end{array}$ & $\begin{array}{l}\text { Number of } \\
\text { productive } \\
\text { stems, } \\
\text { pcs. } / \mathrm{m}^{2}\end{array}$ & $\begin{array}{l}\text { Leangth of } \\
\text { ear, cm }\end{array}$ & $\begin{array}{l}\text { Number of } \\
\text { grains in } \\
\text { an ear, pcs }\end{array}$ & $\begin{array}{l}\text { Weight } \\
\text { of a } \\
\text { grain in } \\
\text { an ear, } \\
\text { g }\end{array}$ \\
\hline \multirow{2}{*}{$\mathrm{N}_{30} \mathrm{P}_{90} \mathrm{~K}_{120}$ - background } & 1 & 443 & 7,5 & 36,4 & 1,52 \\
\hline & 2 & 461 & 7,9 & 39,5 & 1,66 \\
\hline \multirow{2}{*}{$\begin{array}{l}\text { Background }+\mathrm{N}_{60} \text { (lime-ammonium } \\
\text { nitrate) - after SVR }+\mathrm{N}_{60} \text { (ammonium } \\
\text { nitrate) }- \text { initial booting }+N_{10} \text { (urea) - flag } \\
\text { leaf }\end{array}$} & 1 & 499 & 7,9 & 41,2 & 1,76 \\
\hline & 2 & 526 & 8,6 & 42,9 & 1,90 \\
\hline $\begin{array}{l}\text { Background }+\mathrm{N}_{30} \text { (lime-ammonium } \\
\text { nitrate) - after SVR }+\mathrm{N}_{30} \text { (nitrogen-sulfur } \\
\text { fertilizer) - after SVR }+\mathrm{N}_{60} \text { (ammonium }\end{array}$ & 1 & 508 & 8,5 & 41,2 & 1,85 \\
\hline
\end{tabular}




\begin{tabular}{|c|c|c|c|c|c|}
\hline $\begin{array}{l}\text { nitrate) - initial booting. + } N_{10} \text { (urea) - flag } \\
\text { leaf }\end{array}$ & 2 & 533 & 8,9 & 43,8 & 1,98 \\
\hline \multirow{2}{*}{$\begin{array}{l}\text { Background }+\mathrm{N}_{60} \text { (lime-ammonium } \\
\text { nitrate) - after SVR }+ \text { Oracul colofermin } \\
\text { phosphorus, } 2.5 \mathrm{I} / \mathrm{ha} \text { - after SVR }+\mathrm{N}_{60} \\
\text { (ammonium nitrate) - initial booting }+\mathrm{N}_{10} \\
\text { (urea) - flag leaf }\end{array}$} & 1 & 533 & 8,5 & 42,6 & 1,82 \\
\hline & 2 & 558 & 8,8 & 45,9 & 1,97 \\
\hline \multirow{2}{*}{$\begin{array}{l}\text { Background }+\mathrm{N}_{50} \text { (lime-ammonium } \\
\text { nitrate) - after SVR }+\mathrm{N}_{10} \text { (urea foliar) - } \\
\text { after SVR }+ \text { Oracul colofermin } \\
\text { phosphorus, } 2.5 \mathrm{l} / \mathrm{ha}-\text { after SVR }+\mathrm{N}_{60} \\
\text { (ammonium nitrate) }- \text { initial booting }+\mathrm{N}_{10} \\
\text { (urea) - flag leaf }\end{array}$} & 1 & 492 & 9,3 & 49,9 & 2,30 \\
\hline & 2 & 547 & 8,9 & 45,7 & 2,00 \\
\hline
\end{tabular}

Note: 1-care system without Vimpel 2 application; 2-care system with Vimpel 2 application.

Depending on the variants of the research, the quality of products was also formed (Table 3 ). The weight of 1000 grains in the studied variants was in the range of $42.5-45.2 \mathrm{~g}$ and increased in comparison with the control by $2.9-7.6 \%$, respectively. The natural weight of the grain compared to the control due to feeding of crops increased by $4.3-5.2 \%$ and varied little depending on the fertilization systems.

3. Quality of Darunok Podilliawinter wheat grain depending on fertilization and crop care systems, average for 2016-2018

\begin{tabular}{|c|c|c|c|c|c|}
\hline $\begin{array}{l}\text { Fertilization system } \\
\qquad(\text { factor A) }\end{array}$ & $\begin{array}{l}\text { Crop care } \\
\text { (factor B) }\end{array}$ & $\begin{array}{l}\text { Weight } \\
\text { of } 1000 \\
\text { grains, } \\
\mathrm{g}\end{array}$ & $\begin{array}{c}\text { Natural } \\
\text { weight, } \\
\text { g/l }\end{array}$ & $\begin{array}{c}\text { Protein } \\
\text { content, } \\
\%\end{array}$ & $\begin{array}{c}\text { Wet } \\
\text { gluten } \\
\text { content, } \\
\% \\
\end{array}$ \\
\hline \multirow[t]{2}{*}{$\mathrm{N}_{30} \mathrm{P}_{90} \mathrm{~K}_{120}$ - background } & 1 & 41,3 & 721 & 8,6 & 19,3 \\
\hline & 2 & 42,0 & 728 & 8,1 & 17,9 \\
\hline \multirow{2}{*}{$\begin{array}{l}\text { Background }+N_{60} \text { (lime-ammonium } \\
\text { nitrate) - after SVR }+N_{60} \text { (ammonium } \\
\text { nitrate) - initial booting }+N_{10} \text { (urea) - flag } \\
\text { leaf }\end{array}$} & 1 & 43,5 & 752 & 12,1 & 28,1 \\
\hline & 2 & 44,3 & 757 & 11,4 & 26,9 \\
\hline \multirow{2}{*}{$\begin{array}{l}\text { Background }+N_{30} \text { (lime-ammonium } \\
\text { nitrate) - after SVR }+N_{30} \text { (nitrogen-sulfur } \\
\text { fertilizer)- after SVR }+N_{60} \text { (ammonium } \\
\text { nitrate) - initial booting. }+N_{10} \text { (urea) }- \\
\text { flag leaf }\end{array}$} & 1 & 44,9 & 762 & 12,8 & 29,1 \\
\hline & 2 & 45,2 & 766 & 12,3 & 27,9 \\
\hline \multirow{2}{*}{$\begin{array}{l}\text { Background }+\mathrm{N}_{60} \text { (lime-ammonium } \\
\text { nitrate) - after SVR }+ \text { Oracul colofermin } \\
\text { phosphorus, } 2.5 \mathrm{l} / \mathrm{ha}-\text { after SVR }+\mathrm{N}_{60} \\
\text { (ammonium nitrate) - initial booting }+\mathrm{N}_{10} \\
\text { (urea)- flag leaf }\end{array}$} & 1 & 42,5 & 759 & 12,6 & 30,3 \\
\hline & 2 & 42,9 & 765 & 12,1 & 28,6 \\
\hline $\begin{array}{l}\text { Background }+\mathrm{N}_{50} \text { (lime-ammonium } \\
\text { nitrate) - after SVR }+\mathrm{N}_{10} \text { (urea foliar) - } \\
\text { after SVR + Oracul colofermin } \\
\text { phosphorus, } 2.5 \mathrm{l} / \mathrm{ha}-\text { after SVR }+\mathrm{N}_{60}\end{array}$ & 1 & 43,1 & 759 & 12,4 & 28,8 \\
\hline
\end{tabular}




\begin{tabular}{|l|l|l|l|l|l|}
\hline $\begin{array}{l}\text { (ammonium nitrate) }- \text { initial booting }+\mathrm{N}_{10} \\
\text { (urea) - flag leaf }\end{array}$ & 2 & 43,8 & 765 & 12,1 & 27,9 \\
\hline
\end{tabular}

Note: 1-care system without Vimpel 2 application; 2-care system with Vimpel 2 application.

The protein content in the grain averaged $11.4-12.8 \%$ over the years of the researches, the wet gluten content was $26.9-30.3 \%$ to the background $8.1-8.6 \%$ and $17.9-19.3 \%$. The formed gluten by elasticity belongs to the I group (good). In such a case, the treatment of crops with the growth stimulant Vimpel 2 shows a decrease in the average protein content by $0.3-0.8 \%$, gluten content by $0.9-1.7 \%$. According to three-year data, the quality indicators of the obtained grain on the variants with feeding correspond to II-III, on the control - to VI class.

\section{Conclusions}

Having studied the effect of fertilization systems and use of double spraying of crops with growth stimulator Vimpel 2 in combination with pesticides and microfertilizer on productivity and quality of Darunok Podillia winter wheat grain in the conditions of Western Forest-steppe on typical low humus chernozem, it is stated:

The highest yield of winter wheat $7.13 \mathrm{t} /$ ha was provided by the fertilization system $N_{160} P_{90} K_{120}$ with early spring foliar feeding by Oracul colofermin phosphorus (2.5 l/ha) in combination with double spraying of crops with growth stimulator Vimpel $2(0.6 \mathrm{~kg} / \mathrm{ha})$.

It is determined that in the fertilization system, when nitrogen-sulfur fertilizer is applied simultaneously with lime-ammonium nitrate at $30 \mathrm{~kg} / \mathrm{ha} N$ in the early spring feeding, the yield of winter wheat increases by $0.11 \mathrm{t} / \mathrm{ha}$, the protein content in the grain is $12.9 \%$ and the wet gluten contains $27.9 \%$.

Fertilization system, which included foliar application of microfertilizer-compensator Oracul colofermin phosphorus (2.5 I/ha) after the renewal of vegetation on the background of surface feeding with nitrogen fertilizers $\left(N_{60}\right)$, provided a significant increase in winter wheat yield by $4.0-5.0 \%$, relative to background variant.

Double use of growth stimulator Vimpel $2(0.6 \mathrm{l} / \mathrm{ha})$ in combination with pesticides and microfertilizer Oracul multicomplex in the tillering phase and on the flag leaf increased the winter wheat grain output by $9.7-10.9 \%$.

\section{References}

1. Panfilova, A.V., \& Hamaiunova, V.V. (2019). Vplyv sortovykh osoblyvostei ta optymizatsii zhyvlennia na yakist zerna pshenytsi ozymoi v umovakh Pivdennoho Stepu Ukrainy. [Influence of varietal features and nutrition optimization on winter wheat grain quality in the conditions of the Southern Steppe of Ukraine.] (pp. 78-79). Ecological and genetic aspects in the selection of field crops in the context of climate change: Coll. materials International. scientific-practical conf. [in Ukrainian].

2. Petrichenko, V. F., \& Korniychuk, O. F. (2018). Faktory stabilizatsii vyrobnytstva zerna pshenytsi ozymoi v Lisostepu Pravoberezhnomu. [Factors of stabilization of winter wheat grain production in the Right-Bank Forest-Steppe]. Bulletin of Agricultural Science, 2, 17-23. [in Ukrainian].

3. Ivanova, O. M. (2012). Otsenka vliyaniya azotnyih udobreniy na produktivnost sortov ozimoy pshenitsyi na tipichnom chernozeme. [Evaluation of the effect of nitrogen fertilizers on the productivity of winter wheat varieties on typical chernozem]. Agrochemical bulletin, 5, 44-45. [in Russian].

4. Petrychenko, V.F., \& Lykhchvor, V.V. (2020). Roslynnytstvo. Novi tekhnolohii vyroshchuvannia polovykh kultur. [Plant production. New cultivation technologies of agricultural crops]. Lviv: ScientificProduction Firm "Ukr. Tekhnologii». [in Ukrainian]

5. Zheliazkov, O.I. (2011). Formuvannia pokaznykiv yakosti zerna pshenytsi zalezhno vid poperednykiv, strokiv sivby ta normy vysivu nasinnia $v$ Prysyvashshi. [Formation of winter wheat grain quality parameters of depending on predecessors, sowing dates and seeding rates in Prysyvashshia]. Bulletin of the Institute of Grain Management of UAAS, 40, 175-179. [in Ukrainian]

6. Zhemela, H.P. (1991). Dobryva, urozhai i yakist zerna. [Fertilizers, yield and grain quality]. Kyiv: Urozhai. [in Ukrainian]

7. Pryadkina, G.A., Schwartau, V.V., Mihalskaya, L.N. (2011). Potuzhnist fotosyntetychnoho aparatu, zernova produktyvnist ta yakist zerna intensyvnykh sortiv miakoi ozymoi pshenytsi za riznoho rivnia mineralnoho zhyvlennia. [The capacity of photosynthetical apparatus, grain productivity and it quality of intensive varieties of winter wheat at different levels of mineral nutrition]. Physiology and biochemistry of cultivated plants, 43(2), 158-163. [in Ukrainian]

8. Holubchenko, V. F., Lisovyi, M. V., Kulidzhanov, E. V. et al. (2015). Vplyv mineralnykh dobryv na vrozhainist ta yakist zerna pshenytsi ozymoi v roky z riznoiu volohozabezpechenistiu gruntu. [Effect of mineral fertilizers on yield and quality of winter wheat grain in years with different moisture content of soil]. 
Foothill and mountain agriculture and stockbreeding: Interdepartmental thematic scientific collection of the Institute of Agriculture in the Carpathian region NAAS, 58, 1, 51-55. [in Ukrainian].

9. Hlisnikovski, \& L., Kunzova, E.(2014). Effect of Mineral and Organic Fertilizers on Yieldand Technological Parameters of Winter Wheat (Triticum aestivum L.) on Illimerized Luvisol. Polish J. of Agronomy, 17, $18-24$.

10. Nuttall, J.G., O'Leary, G.J., Panozzo, J.F. et al. (2017). Models of grain quality in wheat. Field Crops Research, 202, 15 February, $1-4$. 